\title{
Fishpathogens.EU/NODA: A Free and Handy Online Platform for Betanodavirus Targeted Research and Data Sharing
}

Panzarin, V.; Mikkelsen, Susie Sommer; Jonstrup, Søren Peter; Bigarré, L.; Baud, M.; Gray, T.; Agapow, P.-M.; Olesen, Niels Jørgen

Publication date:

2013

Document Version

Publisher's PDF, also known as Version of record

Link back to DTU Orbit

Citation (APA):

Panzarin, V., Mikkelsen, S. S., Jonstrup, S. P., Bigarré, L., Baud, M., Gray, T., Agapow, P-M., \& Olesen, N. J. (2013). Fishpathogens. EU/NODA: A Free and Handy Online Platform for Betanodavirus Targeted Research and Data Sharing. Poster session presented at 16th International Conference on Diseases of Fish and Shellfish, Tampere, Finland.

- You may freely distribute the URL identifying the publication in the public portal 


\title{
FISHPATHOGENS.EU/NODA: A FREE AND HANDY ONLINE PLATFORM
}

\section{FOR BETANODAVIRUS TARGETED RESEARCH AND DATA SHARING}

\author{
V Panzarin ${ }^{1}$, SS Mikkelsen² ${ }^{\star}$, SP Jonstrup², L Bigarré3 ${ }^{3}$ M Baud ${ }^{3}$, T Gray $^{4}$, P-M Agapow ${ }^{5}$, NJ Olesen² \\ * These authors equally contributed to this work \\ ${ }^{1}$ Research \& Innovation Department - Division of Comparative Biomedical Sciences, OIE Reference Laboratory for Viral Encephalopathy and Retinopathy, Istituto Zooprofilattico Sperimentale delle \\ Venezie, Viale dell'Università 10, 35020 Legnaro, PD, Italy \\ ${ }^{2}$ Section for Fish Diseases, Division of Poultry, Fish and Fur Animals, National Veterinary Institute, Technical University of Denmark, DK-8200 Århus N, Denmark \\ ${ }^{3}$ Fish Viral Pathologies Unit, Laboratoire de Ploufragan/Plouzané, ANSES, Technopole Brest-Iroise, 29200 Plouzané, France \\ 4 Symantix Ltd, Wiltshire SN4 9BN, United Kingdom \\ ${ }^{5}$ Bioinformatics, Centre for Infections, Health Protection Agency (UK), 61 Colindale Avenue, London NW9 5EQ, United Kingdom
}

\section{DATIABASE PRESENTAJIION}

Betanodaviruses are responsible for a severe neuropathological disease known as Viral Nervous Necrosis (VNN) that can affect a broad range of fish species worldwide. Betanodavirus genome consists of two single stranded positive sense RNA molecules, which are susceptible to reassortment events. The phylogenetic analysis of both genetic segments allowed the identification of at least four betanodavirus genotypes, namely RGNNV, SJNNV, BFNNV, TPNNV, as well as the two reassortants RGNNV/SJNNV and SJNNV/RGNNV. The infectivity of betanodavirus to an increasing number of fish species, its wide geographical extent and its economical and ecological impact, highlight the need of a platform for sharing epidemiological and molecular data.

Fishpathogens.eu is a website developed and maintained by the European Union Reference Laboratory for Fish Diseases (EURL-FISH). It has been previously launched for Viral Haemorrhagic Septicaemia (VHS) and Infectious Haematopoietic Necrosis (IHN), and have proven to be a valuable tool for experts targeted research. With the aim of collecting molecular and epidemiological information on betanodavirus, relevant for its control and research study, we extended FishPathogens.eu to also comprise VNN. The present database is going to be a useful tool to better understand betanodavirus diffusive dynamics and ecological features, as well as VNN epidemiology.

\section{HOW CAN THE DAJABASE BE ACCESSED?}

Login is required to upload and download information Everyone can register at www.fishpathogens.eu

Without registering it is still possible to browse reports

Everyone are encouraged to upload new reports

\section{HOW TO RETRIEVE JNEORMAATION?}

\section{Search possibilities by...}

Gene region(s)

Geographical location

Keyword

BLAST

Output

Sampling date

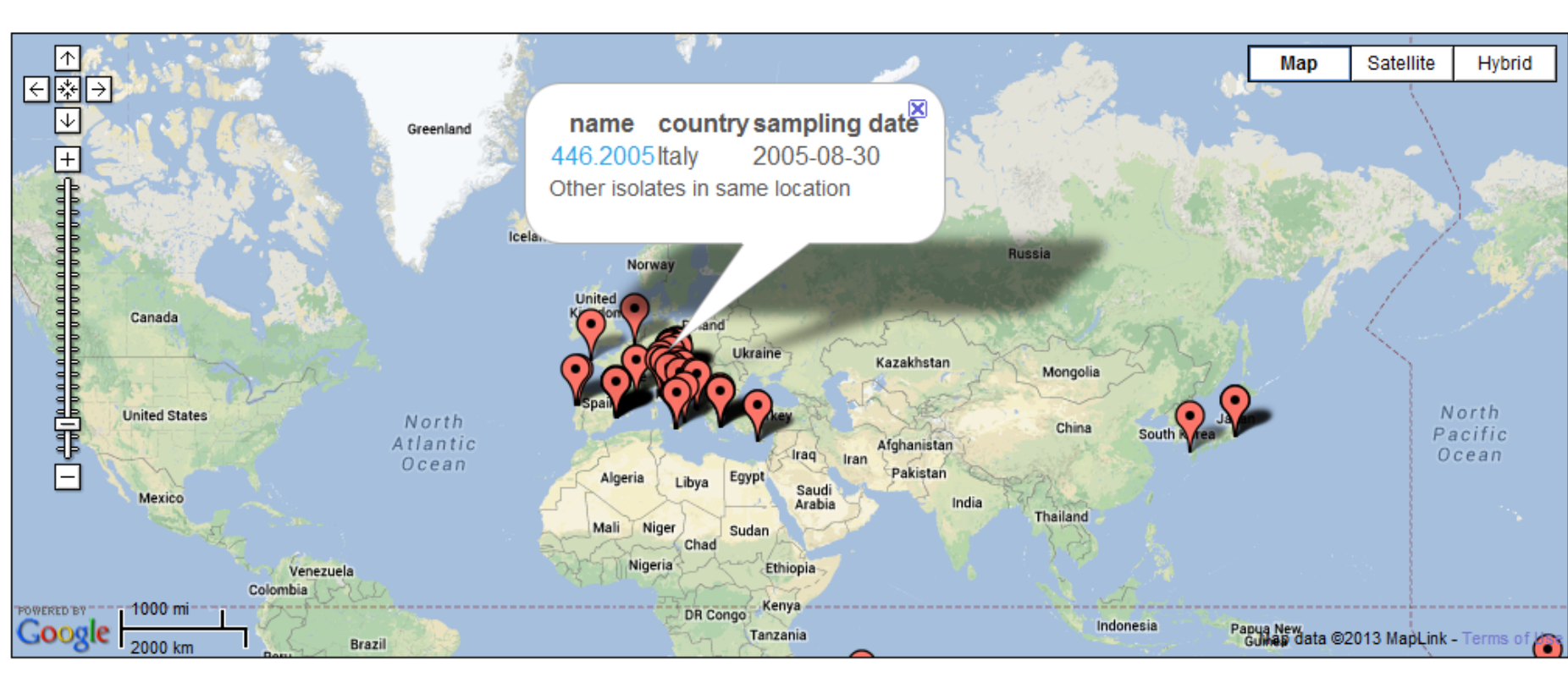

.csv (Excel)

.kml (Google maps)

.Newick (phylogenetic tree)
WHICH JNEORMAAJION CAN BE UPLOADED?

\begin{tabular}{|c|c|}
\hline $\begin{array}{l}\text { Sampling date } \\
\text { Sample information } \\
\text { Geographical location } \\
\text { Water environment } \\
\text { Host species } \\
\text { Epidemiology information } \\
\text { Laboratory source } \\
\ldots\end{array}$ & $\begin{array}{l}\text { Sequence information } \\
\\
\checkmark \text { Nucleotide sequence } \\
\checkmark \text { Gene region(s) } \\
\checkmark \text { Protein name(s) } \\
\checkmark \text { Sequencing method } \\
\checkmark \text { Basic annotation } \\
\checkmark \text { Genotype/Genogroup } \\
\checkmark \ldots\end{array}$ \\
\hline
\end{tabular}

WHICH JOOLS ARE PROVJDED?

New function!

Sequence comparison using .fasta files

Tree building using neighbour-joining

Round or square phylogenetic trees

Export in Newick format 